\title{
Melanoma of the Conjunctiva cT4 TNM
} Finding v7

National Cancer Institute

\section{Source}

National Cancer Institute. Melanoma of the Conjunctiva CT4 TNM Finding v7. NCI

Thesaurus. Code C88657.

Melanoma of the conjunctiva invading the central nervous system. (from AJCC 7th Ed.) 